\title{
Asthma treatment of children and adolescents: Strategies for a global approach
}

\author{
ROBERT L THIVIERGE MD FRCPC \\ Multidisciplinary Asthma Clinic, Hôpital Ste-Justine, Montréal, Québec
}

\begin{abstract}
RL Thivierge. Asthma treatment of children and adolescents: Strategies for a global approach. Can Respir J 1995;2(Suppl A):43A-45A.

Strategies for a global approach to the management of asthma in children and adolescents are described. Such an approach requires the physician to explatin to the pationt the pathophysiology of asthma, to evaluate and, whenever possible, change predisposing environmental factors, to establish a written plan of atction and to maintain a close follow-up of the patient to ensure compliance.
\end{abstract}

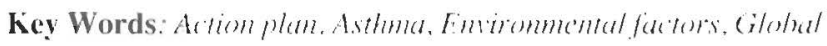
managemint

\section{Le traitement de l'asthme de l'enfant et de l'adolescent : Stratégies pour une approche globale}

RÉSUMÉ : Les stratégies pour une approcho globale de lat prise en charge de l'asthme chez l'enfant et I'adolescent sont décrites. Une telle approche exige du médecin qu'il explique au patient la physiopathologie de l'asthme, qu'il évalue et modifie, quand c'est possible, les facteurs environnementaux prédisposants. Il doit aussi établir un plan d'action écrit et maintenir un suivi rigoureux du patient pour garantir sa fidélité au traitement.
$\mathrm{T}$ HE MANAGEMENT OF THI: ASTHMATIC CHLL HAS changed considerably in the past few years. The detinition of asthma has itself been modified; asthma is no longer defined only as bronchospasm secondary to an allergenic or viral exposure but as a mucosal inflammatory response to an agent or more often to a set of agents that induce and maintuin inflammation ( 1 ).

This article describes at global clinical approach that should be taken by practitioners as educators of asthmatic children and their parents. The following steps will be addressed: explaining the pathophysiology of asthma; changing the avoidable environmental factors; establishing a written action plan with the asthmatic child; and modulating the control visits to ensure compliance.

\section{EXPLAINING THE PATHOPHYSIOLOGY OF ASTHMA}

The primary role of the attending physician is that of educator. It is essential to explain carefully the nature of asthma, distinguishing clearly the two phenomena involved - bronchospasm and inflammation. To illustrate this distinction, it is very useful to draw an analogy with the nasal phenomenon during hay fever season. One observes mucosal edema and sccretions (the inflammatory componcnt) but also sneezing (the dynamic component).

Several factors are known to caltse bronchial inflammation and hyperreactivity. In general, respiratory viruses are the first inductors of the asthmatic responses during the lirst lew years of life. Thus, daycare centres become particu-

Comesyomakence: Mr Robert L Thivierge, Hôpital Sainte-Iustine, 3175. Côte Ste-Catherine. Montréal, Québec H3T IC5. Telephone

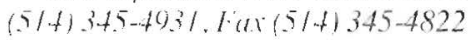


larly fertile reservoirs of such inductions in preschool chit dren.

Later, after infancy, specific allergies develop that may cause asthma: allergies to dust, mites, moulds, cats, dogs, etc (2.3). Special attention must be given to atopic children during the first months of life; their potential for becoming asthmatic is high.

It is also desirable to discuss the characteristic symptoms of asthma (4,5) - coughing, shortness of breath and whec\%ing. For a long time, the wheezing crisis that brought paticnts to emergency rooms associated with the clinical improvement brought on by treatment with an adrenergic agent (subeutaneous noratdrenaline or inhaled salbutamol) wals considered the hallmark of asthna. Today, frequent, repeated and persistent coughing is considered a symptom of asthma. The shortness of breath associated with coughing or wheezing is also part of the sympton triad. If, al one time, it was said that all patients who were wheezing were not necessarily asthmatic (referring to the possibility of an intrabronchial foreign body, for example), today it is recognized that every case of wheezing or coughing should first suggest asthma.

\section{EVALUATING ENVIRONMENTAL FACTORS}

In an effort to explain the recent dramatic increase in asthma cases, attention is now being paid more and more to the macro-environment and phenomena such as industrial pollution, acid rain and changes in the ozone layer.

However, other respiratory irritants are also present in the micro-cnviromment of the home. It is important to know how well the temperature is maintained in an asthmatic child's home between the end of September and the end of May, a period when this micro-cnvironment is self-contained. Ideally, the ambient temperature should be maintained between 18 and $20^{\circ} \mathrm{C}$. It should also be remembered that, over the past 20 years, most houses have been overinsulated and they are frequently overheated. Another important aspect is the humidity level. For several years, it was thought that maintaining a high level of humidity (greatter than 50 to $60 \%$ ) was preferred for every child with respiratory problems. Since the mid $80 \mathrm{~s}$, the opposite has been recommended; the idcal relative humidity level in a house should be between 30 and $45 \%$. Parents should therefore have at hand a thermometer and a hygrometer to monitor and control as efficiently as possible the temperature variations in the house.

Cigarette smoke is another irritant than can and must be absolutely avoided. As physicians, we often leel that our recommendations are not always put into practice, but it has been proven that if we insist, during each visit, on the importance of eliminating tobaceo smoke, parents feel more responsible as far as asthma management is concerned.

\section{ESTABLISHING A WRITTEN PLAN OF ACTION}

To optimize both patient and family treatment compliance, it is of the most utmost importance to give them a treatment diary in which they will describe symptoms and doses of medication for an objective evaluation. Even if an asthmatic paticnt only suffers episodic airway obstruction, it is useful to note these episodes on at calendat and to writc down the medication taken.

For the chronic asthmatic it is very useful and effective to ask, at the start, for the symptoms and drugs used to be noted each day in a diary to indicate clearly the cvolution of the discatse. Follow-up visits should be tused to reinforec the overall management strategy $(6,7)$.

The main consensus recommendations (8-11) all kefine the following drug treatment regimens for the asthmatlic child.

Occasional asthma with symptoms well controlled by at short treatment with adrenergic agents.

Mild asthma with frequent symptoms (cough, shortness of breath, dyspnea, wheezing, more than seven to I0 dalys a month), which interfere very little with everyday activities and rarely cause a visit to the emergency room or hospital admissions. Nonsteroidal agents such as cromoglycate, nedocromil or ketotifen are recommended as first-step treatment, as are the inhaled steroids in the dose range of 200 to $400 \mu \mathrm{g}$ per day. Taken continuously for a few weeks (generally four to six weeks) these drugs will alleviate symptoms in patients with mild asthmar.

Moderate asthma with mor' marked symptoms that requirc visits to the emergency room and sometimes admission to hospital. Corticosteroids at doses ranging from 400 to $800 \mu \mathrm{g}$ per day are used in the long term treatment of noderate asthma.

Severe asthma with daily symptoms that interfere with the child's or teenager's normal life. These patients regularly have to be treated in the emergency room and are often hospitalized. It is often difficult to defer the use of bronchodilators.

Whatever the level of treatment, the signs of an effective control of asthma are the absence of symptoms, being able to pursue everyday activities and, finally, the greatest possible reduction in the use of adrenergic agents $(12,13)$.

The use of pulmonary function measures (spirometry with or without bronchial challenge, peak expiratory flow) is limited in ordinary practice to school age children and adolescents. In children less than five years old, different tests (rapid chest compression in the case of newborn infants, oscillation test in children two to five years old) are available in specialized centres.

For many children with moderate to severe asthıni, serial measurements with a peak expiratory flow meter help both the parents and the doctor to evaluate the airway obstruction crisis objectively and to make more effective adjustments to the long term treatment plan $(14,15)$.

\section{CLOSE FOLLOW-UP AND ACTION PLAN}

When starting treatment, it is essential to plan a close follow-up of the patient. Prescribing inhaled medication during the acute phase and the period immediately following does not mean that an adequate control of asthma will be automatically achieved. Too many unpredictable fictors and difficulties have to be laced, making it is impossible to achicve effective therapy and prevention so easily. Education 
and support are of the utmost importance when the child and his or her parents undertake the task of asthma self-management. This effort must not be andertaken in acontext of crisis. A good relationship has to be established at the beginning of treatment, and must be reinforced every four to six weeks and then at intervals determined by the quality of asthma control. It is also nseful to see a patient again two weeks following a significant exacerbation to review the treatment plan.

The use of an action plan written down by the doctor and given to the pattient at the same time as the symptom diary increases patient compliance and makes him or her feel more responsible for managing the disease. Moreover, because most drugs are delivered by different inhalers, it is essential to ask the patient to bring the medications to the office and demonstrale repeatledly that he or she masters the inhalation technique. The importance given to the effective use of mediation will denonstrate how seriously the maintenance treatment of the asthmatic patient is considered. Finally, it is a good idea to plan in one office session (eg, the same morning or afternoon each week) all appointments of paticnts fol-

\section{REFERENCES}

1. Barnes PJ. A new approith to the trcilment of asthma. N Engl J Med 1989:321:1517-27.

2. Platts-Mills TAE, Chapman MD. Dustmites: immunology, allergic disease and environmental control. J Allergy Clin Immunol 1987;80:755-75.

3. Chapman MD, Platts-Mills TAE. Cat allergy, An Allergy 1992;69:273-5.

4. Thivierge RL, Lapierre JG, Gaudreault P. Traitement de l'asthme en pédiatrie: une approche actualisée. Le Clinicienn 1989:4:23-30.

5. Thivierge RL, Lapierre JG, Gaudreault P. Trattement de l'asthme en pédiatrie (deuxième partic). Le Clinician 1989:4:31-40.

6. Hughes DM, McLeod M, Ganner B, et al. Controlled trial of it home and ambulatory program for asthmatic children. Pediatrics 1991;87:54-61.

7. Mellins RB, Zimmerman B. Clark NM. Patient compliance. Am Rev Respir Dis 1992;146:1,37-77.

8. National Asthma Education Program Expert Pancl Report. Executive Summary: Guidelines for diagnosis and management of asthma. United States Depurtment of Health and Human Services publication 91-3042A. Bethesdit: National Institutes of Health, 1991.

9. Warner JO, Ciotz M, Landau LI, et al. Management of asthma: lowed for asthma; repetitive application of strategies in different types of asthma will reinforce the message that we value a coherent and continuous management of our asthma patients $(10,17)$

\section{CONCLUSION}

The global approach to asthma treatment is much more demanding that the simple prescribing of a specific drug; the essential role of educating children with asthma and their families is the most important of these responsibilities. At the first evaluation and at each follow-up visit, the attending physician must give special attention to all the essentiat factors of successful control of asthma: explain clearly the pathophysiology and significant symptoms of asthma; eliminate systematically all avoidable environmental factors to which the child is exposed; writc down a plan of action for long term management; check regularly the quality of the patient's inhalation technique; and, finally, constantly reinforce the everyday treatment strategy. For the asthmatic child, the ultimate goal is to live a nomal daily lifi.

a consensus statement. Arch Dis Child 1989;04:1065-79).

10. Warner JO, Gotz M, Landau LI, et al. International Pedialric Asthma Consensus Group: a follow-up report. Arch Dis Cluild 1992;67:240-8.

11. Hargreave FE, Dolovich J, Newhouse MT. The assessment and treatment of asthma: a conference report. J Allergy Clin Immunol 1990;85:1098-111.

12. Sears MR, Taylor DR, Print CG, et al. Regular inhaled $\beta$-agonist treatment in bronchial asthma. Linncet 1990;336:1391-6.

13. Page CP. One explanation of the asthma paradox: inhibition of natural anti-inflammatory mechanism by $\beta 2$-agonists. Lancet 1991:337:717-20.

14. Meltzer AA, Smolensky MH, D'Alonzo GE, et al. An assessment of peak expiratory flow as a surrogate measurement of $\mathrm{FEV}_{\mathrm{I}}$ in stable asthmatic children. Chest 1989;96:329-33.

15. Mueller GA, Eigen H. Pulmonary function testing in pediattric practice. Pediatr Rev 1994;10:403-11.

16. Clark NM, Gotsch A, Rosenstock R. Patient, professional and public education on behavioral aspects of asthma: a review of strategies for change and needed research. J Asthma 1993;30:241-55.

17. St-Laurent-Gagnon T, Turgeon JP, Bemard-Bumnin AC at al Teaching inhalation techniques to asthmatic children: a randomized trial. Pediatrics. (In press) 


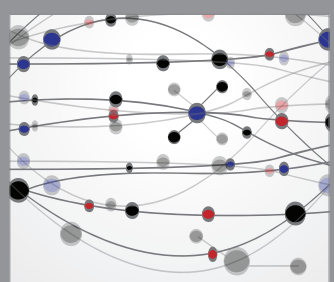

The Scientific World Journal
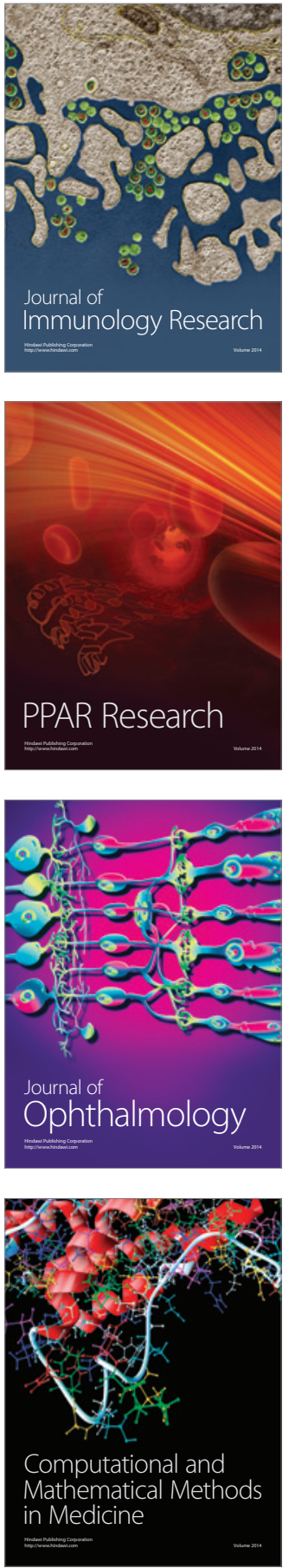

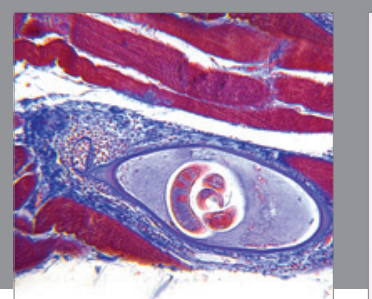

Gastroenterology Research and Practice

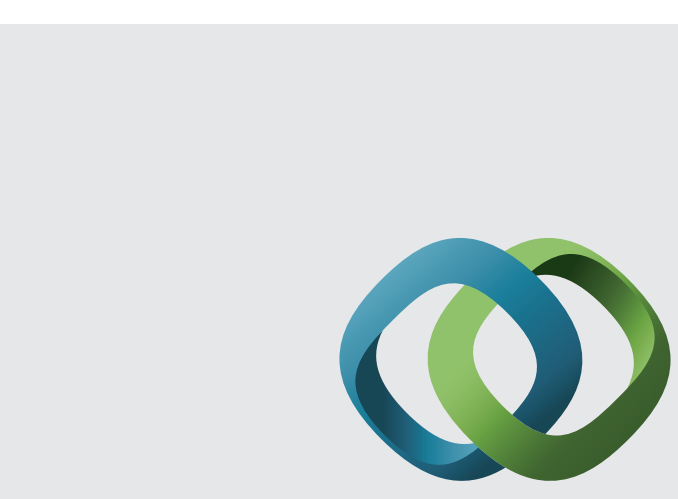

\section{Hindawi}

Submit your manuscripts at

http://www.hindawi.com
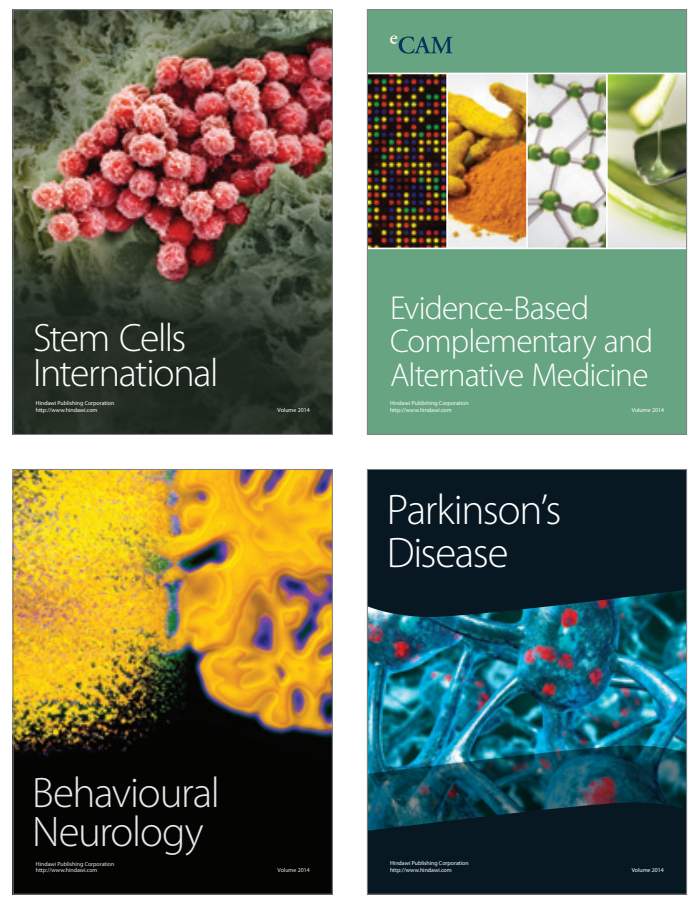
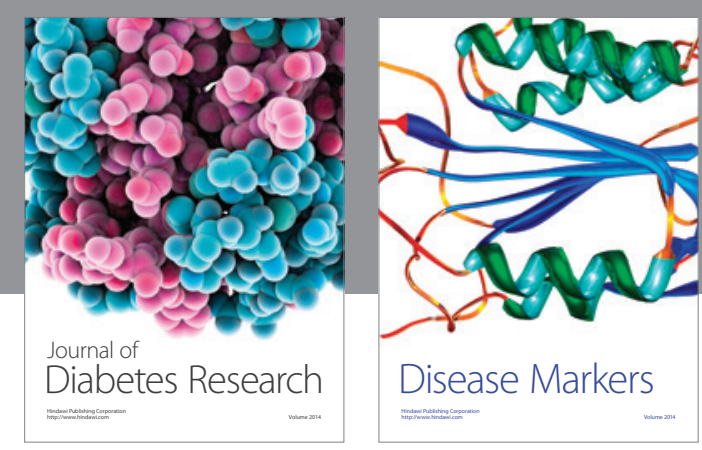

Disease Markers
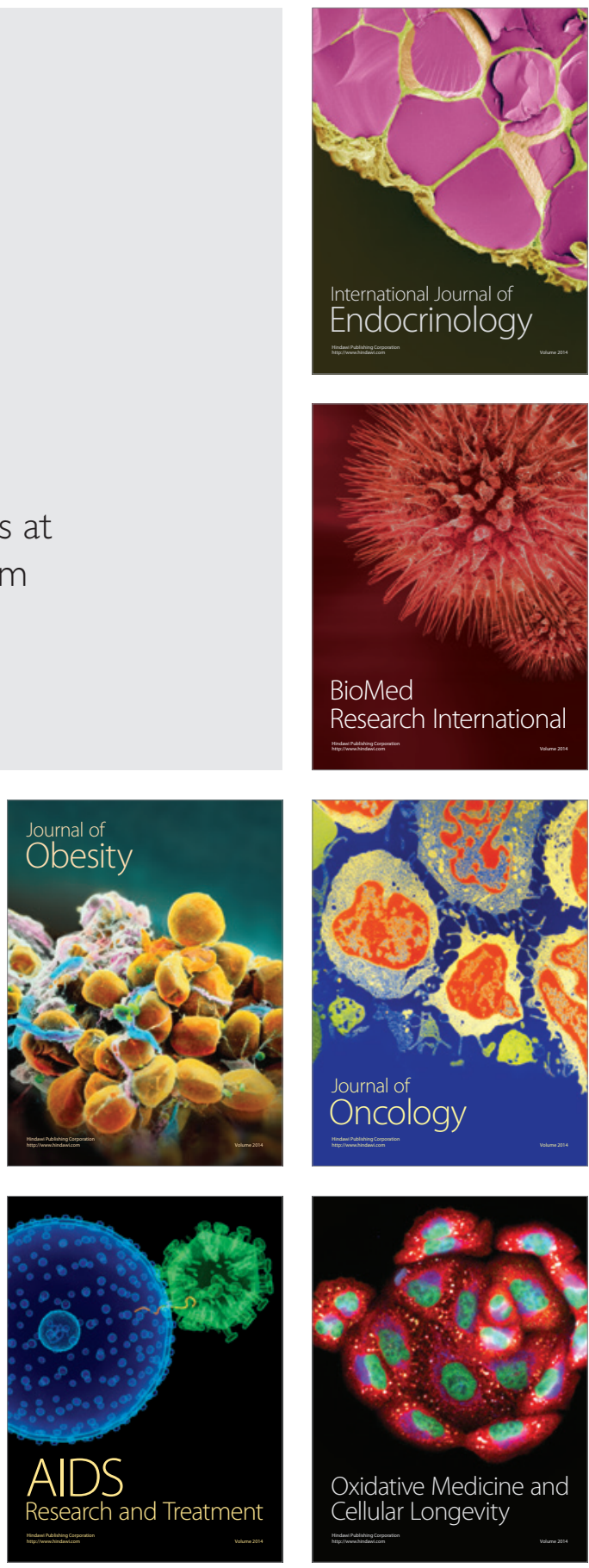